\title{
EFFECT OF SPENT MUSHROOM SUBSTRATE ON THE GROWTH AND YIELD OF THREE CULTIVARS OF MUSKMELONS (Cucumis melo)
}

\section{Thi Oanh Nguyen ${ }^{1 \#}$, Thi Diem Nguyen ${ }^{1 \#}$, Hai Thi Hong Truong ${ }^{1}$, Thi Thu Hang La ${ }^{2}$, Thi Kim Cuc Nguyen ${ }^{1 *}$}

\footnotetext{
${ }^{1}$ Institute of Biotechnology, Hue University, Road 10, Phu Thuong, Phu Vang, Thua Thien Hue, Vietnam

${ }^{2}$ Agronomy Faculty, Hue University of Agriculture and Forestry, 102 Phung Hung, Thuan Thanh, Thua Thien Hue, Vietnam

\#Authors contributed equally to this work.
}

Received - April 27, 2021; Revision - June 01, 2021; Accepted - June 20, 2021

Available Online - June 25, 2021

DOI: http://dx.doi.org/10.18006/2021.9(3).276.286

KEYWORDS
Muskmelons
PN 128
RZ F1
TL3
Spent mushroom substrate
Plant growth

\begin{abstract}
Muskmelons are currently grown in several areas of Vietnam for domestic and international consumer markets. The fruit grows well in greenhouses in soil or soilless substrate such as coconut peat. Researchers in Vietnam are investigating the growth of muskmelons in a range of organic by-products. In this study, spent mushroom substrate was recycled for use as an organic substrate and to evaluate the growth, quality, and yield of three muskmelon varieties including RZ F1, PN 128, and TL3 in greenhouses over three months. The substrate was incubated for one month before use and contained $45 \%$ spent mushroom substrate, $30 \%$ manure, $7.7 \%$ rice husks, $1.5 \%$ phosphorus, $0.2 \%$ commercial Trichoderma (Tribac), $0.1 \%$ rice bran, $15 \%$ sand, and $0.5 \%$ micronutrients and water. Following incubation, the substrate had optimal $\mathrm{pH}$ for the growth of muskmelon and the concentration of nutrients and beneficial microorganisms had increased significantly. The growth of RZ F1 and TL3 cultivars was significantly better than PN 128 in terms of growth, fruit quality, and yield. Specifically, RZ F1 and TL3 species took 78 days and 75 days to complete their life cycle produced $1.76 \mathrm{~kg}$ and $1.62 \mathrm{~kg}$ of fruit, had a pericarp thickness of $4.0 \mathrm{~cm}$, and possessed $14.20^{\circ}$ Brix and $14.88^{\circ}$ Brix of soluble solid content, respectively. These findings suggest that agricultural by-products, such as spent mushroom substrate, could be a valuable resource for the culture of muskmelons in Vietnam.
\end{abstract}

* Corresponding author

E-mail: ntkcuc.huib@hueuni.edu.vn (Thi Kim Cuc Nguyen)

Peer review under responsibility of Journal of Experimental Biology and Agricultural Sciences.

Production and Hosting by Horizon Publisher India [HPI] (http://www.horizonpublisherindia.in/).

All rights reserved.
All the articles published by Journal of Experimental Biology and Agricultural Sciences are licensed under a Creative Commons Attribution-NonCommercial 4.0 International License Based on a work at www.jebas.org.

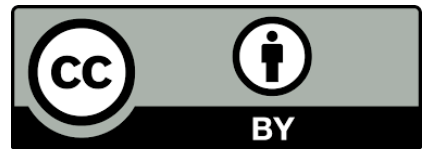




\section{Introduction}

Muskmelons (Cucumis melo L.) are a species of melon that belongs to the Cucurbitaceae family, which have been developed into many cultivated varieties such as honeydew, cantaloupe, and casaba. These muskmelon cultivars require a long-warm growing season (Basham \& Ells, 1988; Mrema \& Maerere, 2018; Dube et al., 2020) that is quite suitable for the climate of Vietnam. Cultivated muskmelons usually are high-quality F1 hybrid seeds that not only give good shape and good taste with a high content of beta-carotene, vitamin $\mathrm{A}$, and vitamin $\mathrm{C}$ but also produce various phytochemicals that have potential as treatments for some human diseases such as heart disease, cancer, respiratory disease and immune deficiency (Lester, 1997; Lester, 2008; Lester \& Hodges, 2008). Therefore, muskmelons are recommended for use in severa countries such as America, Japan, and European countries to reduce the risk of cancer and other chronic diseases, and improve the immune system (Lester, 1997; Lester, 2008). Currently, muskmelons are grown in many countries such as China, Australia, Southwest Asia, India, Turkmenistan, Tajikistan, and so on (Thakur et al., 2019). The production of muskmelons is rapidly increasing every year, and in 2019 global production of this fruit was about 27.50 million tons from a cultivated area of about 1.04 million ha (FAO, 2020). In Vietnam, many producers and farmers have experience in growing different varieties of muskmelons to meet the demand of consumers, and these kinds of muskmelons are normally imported from Japan, Peru, Taiwan or grown from domestic hybrid seed (Nguyen \& Wang, 2017). Growing of muskmelons has been well established in Vietnam since 2017 (Thai News Service Group, 2017). Normally, the seed is germinated in pots to yield quality seedlings before transplant to the soil, hydroponic culture, or artificial substrate (Othman et al., 2019; Schiavi et al., 1994). However, the soil culture of melons may have problems related to plant diseases since traditional growing areas are a source of harmful organisms. Hydroponic systems for growing melons has been investigated since the 1990s (Schiavi et al., 1994; Ikeda et al., 1996; Rodriguez et al., 2005), but the quality of the fruit needs to be improved since hydroponicallygrown melons have vegetative vigor but produce fruit with lower sugar content (Brix around $11^{\circ}$ ) ( Schiavi et al., 1994; Rodriguez et al., 2005). Recently, some countries such as Taiwan, Malaysia and Japan have developed efficient hydroponic systems that yield highquality fruit ( Fatahian et al., 2012; Asaduzzaman et al., 2018; Yam et al., 2020). However, these systems may not be suitable for some countries, especially in poorer regions.

Vietnam has suitable weather for growing muskmelons four seasons per year. Some high-tech areas in Vietnam cultivate muskmelons in greenhouses with a hydroponic system but most farmers grow this fruit in the greenhouses, using soil or substrate (mostly coconut peat). There have been some attempts to produce organic substrates from agricultural residue such as spent mushroom residue to culture this plant (Nguyen et al., 2020).

Cultivation of mushrooms is well developed in Vietnam but after harvesting mushrooms, a lot of waste remains (spent mushroom substrate) which needs to be discarded (Nguyen, 2019). Spent mushroom substrate still has a lot of nutrients that can recycle (Rinker, 2002; Othman et al., 2020). Previously, some research groups tried to recycle this resource to make organic fertilizer, and organic substrate to grow vegetables and fruit (Nguyen, 2016; Nguyen et al., 2020). The use of spent mushroom substrate is an ongoing issue in the management of the waste resource. Therefore, further studies are needed to develop environmentally and economically sustainable agricultural development strategies for use of this valuable resource (Rinker, 2002; Rinker, 2017; Hanafi et al., 2018; Antunes et al., 2020).

In a previous study, Nguyen et al. (2020) pointed out that spent mushroom substrate from Pleurotus ostreatus, and Volvariella volvacea production was a more suitable substrate for the cultivation of muskmelon Inthanon RZ F1 cultivar than that from Ganoderma lucium production or soil medium (fluvisols without annual accretion). The current study aimed to further evaluate the growth of three muskmelon varieties in the spent mushroom substrate and to establish the hypothesis that spent mushroom substrate could be used efficiently in the muskmelon production industry.

\section{Materials and Methods}

\subsection{Materials}

Three muskmelon seed F1 varieties including Inthanon RZ F1, PN 128 , and TL3 were used in this study. Seeds of Inthanon RZ F1 procured from the Rijk Zwaan company (Golden Emerald) originates from Peru; while seeds of PN 128 were selected from Phu Nong, a domestic company; and TL3 (Cantaloupe) from Japan, being imported to Vietnam by the Chanh Phong Company. Spent mushroom residue from Pleurotus ostreatus and Volvariella volvacea was collected from the mushroom production farms at Thua Thien Hue province, Vietnam.

\subsection{Methods}

\subsubsection{Processing and analysis of spent mushroom substrate}

Processing for one ton of spent mushroom substrate mainly contained $45 \%$ Pleurotus ostreatus, and Volvariella volvacea byproducts, $30 \%$ manure, $7.7 \%$ rice husks, $1.5 \%$ phosphorus, $0.2 \%$ (2 $\mathrm{kg}$ ) commercial Trichoderma (Tribac), 0.1\% (1 kg) rice bran (Mixed with commercial Trichoderma), $15 \%$ sand and $0.5 \%$ micronutrient (added immediately before transplanting), and water 
as previously recommended by Nguyen et al. (2020). All of these components, except sand and micronutrients, were mixed carefully until the substrate moisture reached $60-65 \%$. Then, the substrate was incubated and covered with tarpaulin to achieve an appropriate incubation temperature $\left(60-65^{\circ} \mathrm{C}\right)$. After 3 days, the temperature and humidity was checked by a mini thermometer and humidity hygrometer (HT-350, RH 0-100\%, T $-30^{\circ} \mathrm{C}-100^{\circ} \mathrm{C}$ ). At this time, the moisture and temperature of the substrate reached satisfactory levels at $60-65 \%$ and $60-65^{\circ} \mathrm{C}$, respectively. After being incubated for 15 days, the spent mushroom substrate was remixed and the moisture and temperature checked before being incubated again for further 15 days. Then, the spent mushroom substrate was mixed with $15 \%$ of sand, and $0.5 \%$ ( $5 \mathrm{~kg}$ ) of micronutrients to prepare for growing plants.

Samples of $P$. ostreatus, and $V$. volvacea by-product, and spent mushroom substrate were analysed to determine $\mathrm{pH}$ using a $\mathrm{pH}$ meter (Hanna HI 9025; Hanna, Woonsocket, RI, USA). The total organic matter content (HC\% or OM\%) was determined according to the Walkley-Black method (Walkley \& Black, 1934) based on Vietnam National Standards (TCVN) 9294: 2012. Total nitrogen (N\%) was determined by the Kjeldahl method (Bradstreet, 1954) based on TCVN 8557:2010. The phosphorus content $\left(\mathrm{P}_{2} \mathrm{O}_{5} \%\right)$ was determined by a colorimetric method (Fiske \& Subbarow, 1925) in accordance with TCVN 8559:2010. Capillary electrophoresis (CE) was used to analyse Streptocymces (CFU/g), Trichoderma (CFU/g), and Azotobacter (CFU/g) based on TCVN 6166:2002, base Standards of the Plant Protection Department (TCCS) 39:2012/BVTV, and TCVN 6166:2002, respectively. Each sample had five replicates.

\subsubsection{Sowing muskmelon seed}

Germination of three cultivars was carried out at the greenhouse of the Institute of Biotechnology, Hue University. The seed-starting formula contained $70 \%$ spent mushroom substrate and 30\% tribat soil (commercial product from Sai Gon Xanh Company) was transferred to seed nursery trays with 100 holes. The nursery tray has $56 \mathrm{~cm}$ in length $\mathrm{x} 36 \mathrm{~cm}$ in width $\mathrm{x} 4 \mathrm{~cm}$ in height; each hole was 4 $\mathrm{cm}$ in diameter and $4 \mathrm{~cm}$ in depth. After that, seeds were sown directly into each hole and substrate moisture was checked every day by mini thermometer and humidity hygrometer (HT-350, RH 0 $100 \%, \mathrm{~T}-30^{\circ} \mathrm{C}-100^{\circ} \mathrm{C}$ ). The optimal moisture and temperature for seed germination was $60-70 \%$ and $25-30^{\circ} \mathrm{C}$, respectively. After 7 to 10 days, seeds emerged; these seedlings were moved to a location with more sunlight to prepare for transplant.

\subsubsection{Planting muskmelon seedling}

Muskmelon seedlings with three true leaves and 7-10 cm in height were transplanted to polyvinyl pots. The pots were $40 \times 20 \mathrm{~cm}$ in size, and each contained $5 \mathrm{~kg}$ of spent mushroom substrate. All three selected muskmelon cultivar plants were grown on the spent mushroom substrate in the greenhouse from July to September 2020. In total, there were three treatments and each treatment had 30 biological replicates, giving a total of 90 pots. The distance between pots was $40 \mathrm{~cm}$, and that between rows was $120 \mathrm{~cm}$, as previously suggested by Nguyen et al. (2020).

\subsubsection{Muskmelon plant care}

Farming methods were applied following National Technical Regulation (QCVN) 01-91:2012/BNNPTNT on watermelon varieties and the technical vegetable cultivation textbook of Truong (2018). The standard horticultural techniques are as follows

Watering: Muskmelon plants were watered twice a day with 0.60.8 liters/plant. This amount increased to 1.0 or 1.5 liters/plant when plants had developed more vegetative branches, tendrils, flowers, and fruits. The amount of water was reduced when fruit was ripening (about 70 days after transplant).

Fertilizer: Fertilizer was supplemented 15 days after planting with a dose of $50 \mathrm{~g}$ of earthworm fertilizer and $1 \mathrm{~g}$ NPK soluble fertilizer per plant (Nguyen et al., 2020). The same dosage of fertilizer as above was supplied when plants produced the first female flowers and again when the first fruit, respectively. Potassium fertilizer with a dose of $1 \mathrm{~g}$ per plant was applied on the first day of the fruit set and again 10 days later.

Pollination and fruit pruning: All sub-branches and female flowers were pruned off from the base to the 8th leaf. Manual pollination was started from the 9th leaf to the 13th leaf (normally 3-4 fruit set). Once fruiting had occurred, fruit determination was conducted based on the criteria of size and shape (Truong et al., 2019; Nguyen et al., 2020). The selected fruits were wrapped in non-woven bags and hung on sturdy wires. Then, the remaining fruits were cut off, the top of plants and other flower buds were pruned when plants had 23-24 true leaves to focus on fruiting nutrition.

Harvesting: The fruits were harvested when the rinds changed colour from green to tan or yellow, the stem had cracked at the point of attachment, and the degree of sweetness was more than $12{ }^{\circ}$ Brix (Truong et al., 2019).

Pest management: Insect traps were used in this experiment to prevent thrips, whitefly during plant growth and development. Preventive spraying for plants with nano-copper and nanosilver product (From HLC Hanoi Corporation) was sprayed to prevent diseases such as downy mildew after planting three to four days and when the plants began to bear fruit (Nguyen et al., 2020). 


\subsubsection{Muskmelon growth and yield analysis}

Plant growth indicators were collected during 90 days from sowing, germination, production of three true leaves (days), to the production of tendrils, vegetative branches (sub-branches) (day), male flowers, female flowers, fruit selection, and fruit ripening. Leaf morphological features such as leaf length and width were measured with a tape measure in centimeters at longest and widest points, respectively. The plant height was measured with a tape measure. The numbers of female and male flowers are counted during plant growth.

The fruit diameter was measured at the widest point (in $\mathrm{cm}$ ), fruit length was measured from top to bottom of the fruit, the thickness of the pericarp $(\mathrm{cm})$ was the distance measured from the peel to the core, and the total soluble solids content (SSC) of fruits was determined using a refractometer, and was converted Brix degree (Eshed \& Zamir, 1994; Ito et al., 2001; Fu et al., 2009). Other criteria on fruit including shape, peel colour, and flesh colour was analysed at the harvest stage. comparisons between treatment means were made using Tukey's honestly significant difference (HSD) post hoc test.

\section{Results}

\section{1 pH, nutrient and microorganism content of the spent mushroom substrate}

The incubation period had a positive effect on the $\mathrm{pH}$, nutrient content, and microorganism content of the spent mushroom substrate (Table 1). $\mathrm{pH}$ decreased significantly $(\mathrm{P}<0.05)$ from 7.83 on day 0 to 6.54 at the last incubation day (day 30) (Table 1). The organic matter content (OM\%) at day 30 was higher than that at day $0(37.47 \%$ compared to $35.59 \%)$. Similarly, the nitrogen, phosphorus, and potassium contents were significantly higher at day 30 than at day 0 . Specifically, the nitrogen and potassium content approximately doubled from $0.73 \%$ and $0.45 \%$ (day 0) to $1.34 \%$ and $0.92 \%$ (day30), respectively. Furthermore, the digestible nitrogen, phosphorus, and potassium content were markedly increased in the spent mushroom

Table 1 Effects of incubation period on $\mathrm{pH}$, nutrients', and microorganisms' content in the spent mushroom substrate

\begin{tabular}{|c|c|c|c|}
\hline \multirow[b]{2}{*}{ Items } & \multicolumn{2}{|c|}{ Incubation period+ } & \multirow[b]{2}{*}{ LSD $<0.05$} \\
\hline & Initial & Finished & \\
\hline $\mathrm{pH}$ & $7.83^{\mathrm{b}}$ & $6.54^{\mathrm{a}}$ & $<0.05$ \\
\hline $\mathrm{OM} \%$ & $35.59^{\mathrm{b}}$ & $37.47^{\mathrm{a}}$ & $<0.001$ \\
\hline $\mathrm{N} \%$ & $0.73^{\mathrm{b}}$ & $1.34^{\mathrm{a}}$ & $<0.001$ \\
\hline $\mathrm{P}_{2} \mathrm{O}_{5} \%$ & $0.39^{\mathrm{b}}$ & $0.58^{\mathrm{a}}$ & $<0.001$ \\
\hline $\mathrm{K}_{2} \mathrm{O} \%$ & $0.45^{\mathrm{b}}$ & $0.92^{\mathrm{a}}$ & $<0.001$ \\
\hline $\mathrm{N}(\mathrm{mg} / 100 \mathrm{~g})$ & $23.18^{\mathrm{b}}$ & $52.59^{\mathrm{a}}$ & $<0.001$ \\
\hline $\mathrm{P}_{2} \mathrm{O}_{5}(\mathrm{mg} / 100 \mathrm{~g})$ & $25.30^{\mathrm{b}}$ & $28.02^{\mathrm{a}}$ & $<0.001$ \\
\hline $\mathrm{K}_{2} \mathrm{O}(\mathrm{mg} / 100 \mathrm{~g})$ & $25.08^{\mathrm{b}}$ & $71.91^{\mathrm{a}}$ & $<0.001$ \\
\hline Streptomyces content (CFU/g) & 0.00 & $9.52 \times 10^{4}$ & $<0.001$ \\
\hline Trichoderma content (CFU/g) & 0.00 & $2.26 \times 10^{4}$ & $<0.001$ \\
\hline Azotobacter content $(\mathrm{CFU} / \mathrm{g})$ & 0.00 & $4.46 \times 10^{4}$ & $<0.001$ \\
\hline
\end{tabular}

Values are mean \pm SEM, $n=5$. Means labelled with the same letter in a row were not significantly different at the $\mathrm{P}<0.05$ level

(Tukey's HSD). + Incubation substrate of the initial day (day 0 ) and finished day (day 30).

\subsection{Statistical analysis}

All statistical analyses were performed using Microsoft Excel 2016 (Office 365, version 16.36) ProPlus and SPSS software (Version 20) ( $p<0.05)$. For the nutrients and microorganism content data, the response variables were subjected to one-factor analysis of variance (ANOVA) with incubation days as a treatment factor. For the morphological growth and fruit yield data, one-way ANOVA was applied with muskmelon cultivars as the factor. Following ANOVA, where there was a significant main effect or interaction, substrate after the incubation stage (Table 1), increasing from around $23.18 \mathrm{mg} / 100 \mathrm{~g}$ to $52.59 \mathrm{mg} / 100 \mathrm{~g}$, from $25.30 \mathrm{mg} / 100 \mathrm{~g}$ to $28.02 \mathrm{mg} / 100 \mathrm{~g}$ and from $25.08 \mathrm{mg} / 100 \mathrm{~g}$ to $71.91 \mathrm{mg} / 100 \mathrm{~g}$, respectively. Noticeably, the digestible potassium content on the last incubation day was three times higher than that at the beginning of incubation. In addition, the abundance of beneficial microorganisms in the spent mushroom substrate increased substantially after incubation including Streptomyces $\left(9.52 \times 10^{4}\right.$ CFU/g), Trichoderma (2.26 x 10\%/CFU/g), and Azotobacter (4.46 x $10^{4} / \mathrm{CFU} / \mathrm{g}$ ) (Table 1 ). 
3.2 The life cycle and vegetative growth of three muskmelon plants

In general, RZ F1, PN 128, and TL3 muskmelon plants grew effectively on the spent mushroom substrate, but their life cycles were substantially different from each others (Figure 1). While PN 128 muskmelon plants took 85 days to complete their entire life cycle, while this period was 78 days and 75 days for the RZ F1 and TL3 muskmelon plants, respectively. Seed germination was similar, taking around 5 days, in each case. PN 128 muskmelon plants took a further 18 days to produce three true leaves, whereas RZ F1 and TL3 took only 15 days and 14 days, respectively. Furthermore, PN 128 muskmelon plants needed two days longer than the other two cultivars to produce tendrils and vegetative shoots. However, while PN 128 and TL3 took 10 days to move from the flowering stage to the fruit selection stage, RZ F1 took 7 days. PN 128 fruits needed 40 days to ripen which was higher than RZ F1 fruits by one day and TL3 fruits by three days $(\mathrm{P}<0.001$, Table 2).
PN 128 muskmelon cultivars, but there was no significant difference in stem diameter $(\mathrm{p}>0.05)$. In addition, the stem height of the TL3 muskmelon cultivar was similar to that of RZ F1 muskmelon plants (around $230 \mathrm{~cm}$ ) and higher than that of PN 128 muskmelon plants $(218.20 \mathrm{~cm})$. By contrast, the numbers of vegetative shoots, female flowers, and male flowers of TL3 muskmelon plants were dramatically lower than those of RZ F1 muskmelon plants but were not significantly different from those in PN 128 muskmelon plants (Table 3).

\subsection{Fruit morphology, yield and quality}

Fruit morphology of three muskmelon cultivars was analyzed at harvest as indicated in Table 4 . These indicators clearly showed the uniqueness of each muskmelon cultivar. Fruit of RZ F1 and TL3 were circular, while these were oval-shaped in PN 128. Fruit peel color was also different, being yellow in RZ F1, yellowish blue in PN 128, and dark blue in TL3. Furthermore, the fruit flesh color of RZ F1 fruits was bluish-white, whereas it was orange in

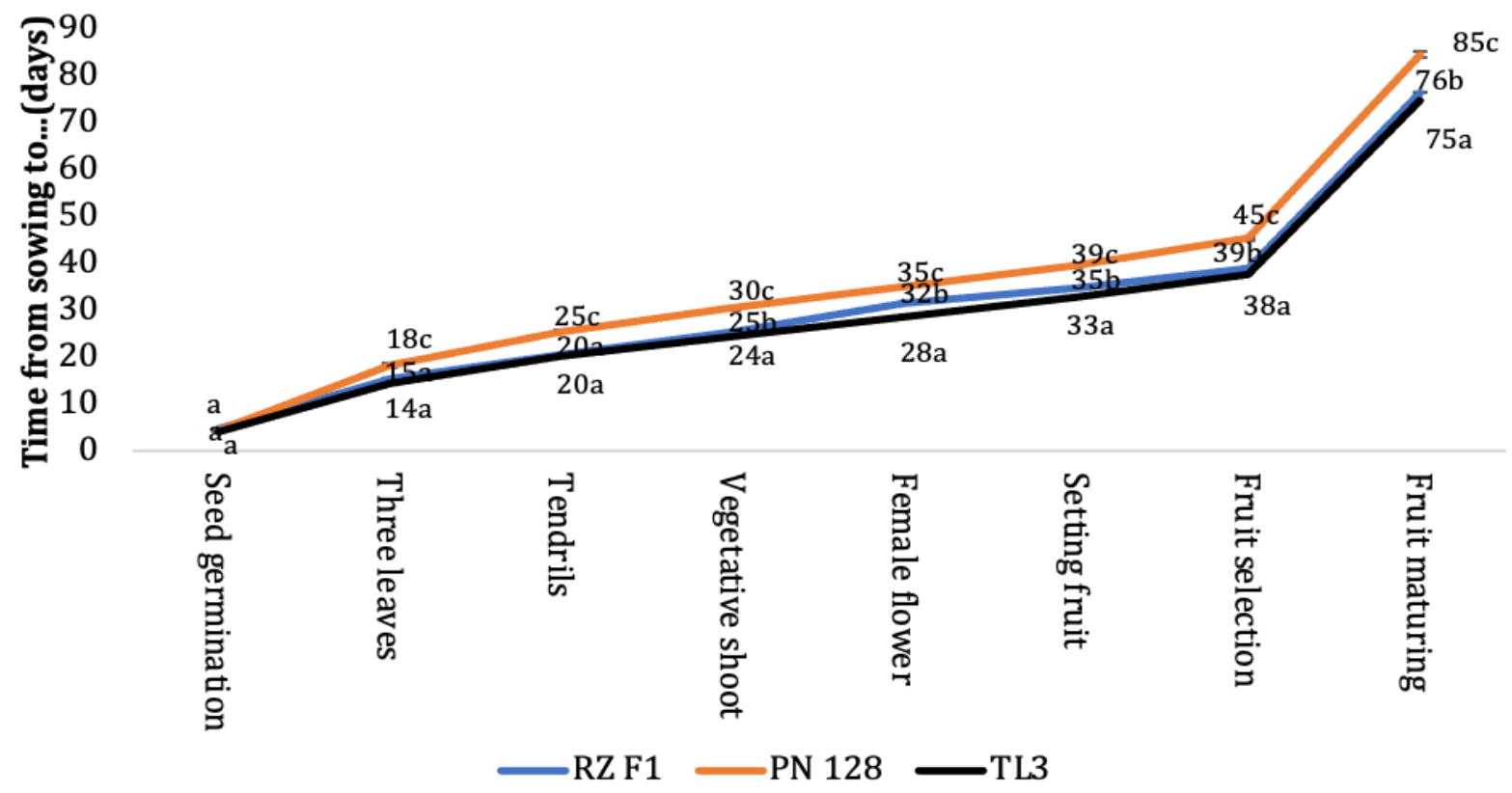

Figure 1 Time (days) from sowing to different stages of three muskmelon cultivars including RZ F1, PN 128, and TL3 growing on the spent mushroom substrate. Values are mean \pm SEM, $n=30$. Means labelled with the same letter were not significantly different at the $P$ $<0.05$ level (Tukey's HSD), see Table 2 for details of ANOVA results.

\subsection{Morphological growth and development}

The effects of spent mushroom substrate on the morphological growth and development of three muskmelon seedlings are shown in Table 3. Analysis of variance indicated significant differences among growth indicators of the three muskmelon cultivars ( $<<0.05$, Table 2). Specifically, leaf length and leaf width of the TL3 muskmelon cultivar were greater than those of at RZ F1 and
PN 128 and TL3. Noticeably, all these kinds of muskmelon fruits had thick, clear, and white patterns in the skin (Table 4).

There was a considerable difference in the yield and quality of three muskmelon cultivar fruit (Figure 2). RZ F1 fruit length was significantly higher than that of TL3 but its fruit diameter was similar to that of TL3 (Figure 2a), while PN 128 fruit had the lowest fruit length and diameter $(\mathrm{p}<0.05$, Table 2$)$. In terms of fruit weight, 
RZ F1 fruits were around $1.8 \mathrm{~kg} /$ fruit, while this fruit was lower for TL3 and PN 128 and it was around $1.6 \mathrm{~kg} /$ fruit and1.4 kg/fruit, respectively (Figure $2 \mathrm{~b}$ ). The thickness of the pericarp was about 4.0 $\mathrm{cm}$ for RZ F1. This was similar to that of TL3 but higher than that of
PN 128 (nearly $3.5 \mathrm{~cm}$ ) (Figure 2c). However, the soluble solids content of RZ F1 fruits was around $14.0^{\circ}$ Brix, which was dramatically lower than that in TL3 fruits (nearly $15.0^{\circ}$ Brix). This number was only around $13.5^{\circ}$ Brix in PN 128 fruits (Figure 2d).

Table 2 Statistical outcomes of one-way ANOVA for a range of plant physiological variables, and fruit yield and quality

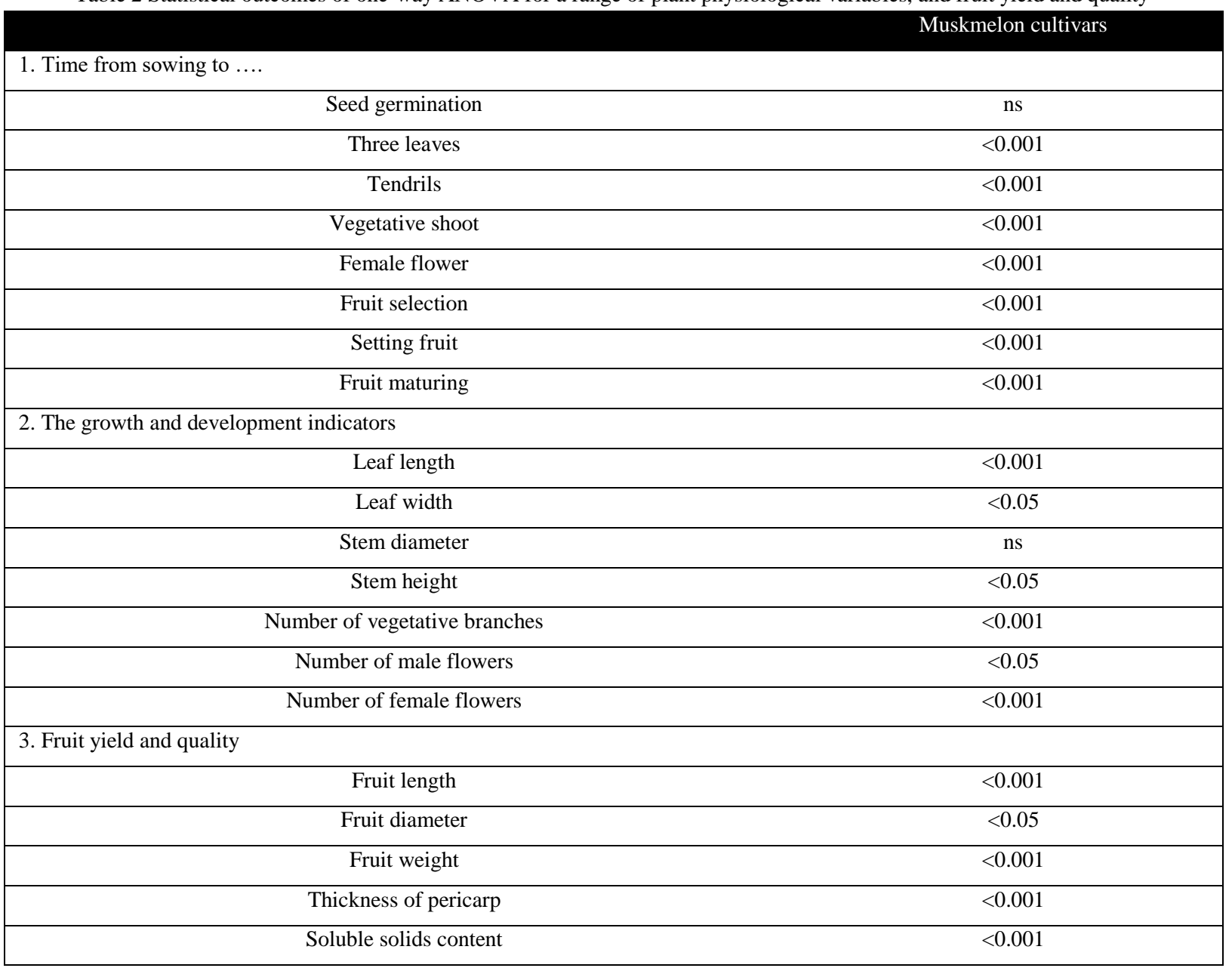

Table 3 Effect of spent mushroom substrate on the morphological growth of cultivars

\begin{tabular}{|cccccccc|}
$\begin{array}{c}\text { Muskmelon } \\
\text { cultivars }\end{array}$ & $\begin{array}{c}\text { Leaf } \\
\text { length }(\mathrm{cm})\end{array}$ & $\begin{array}{c}\text { Leaf } \\
\text { width }(\mathrm{cm})\end{array}$ & $\begin{array}{c}\text { Stem } \\
\text { diameter } \\
(\mathrm{cm})\end{array}$ & $\begin{array}{c}\text { Stem height }+ \\
(\mathrm{cm})\end{array}$ & $\begin{array}{c}\text { Vegetative } \\
\text { shoots+ } \\
(\text { number })\end{array}$ & $\begin{array}{c}\text { Female } \\
\text { flowers+(number) }\end{array}$ & $\begin{array}{c}\text { Male flowers+ } \\
(\text { number })\end{array}$ \\
\hline RZ F1 & $24.60^{\mathrm{b}} \pm 0.13$ & $18.80^{\mathrm{b}} \pm 0.29$ & $0.83^{\mathrm{a}} \pm 0.02$ & $230.70^{\mathrm{a}} \pm 1.91$ & $18.40^{\mathrm{a}} \pm 0.24$ & $13.60^{\mathrm{a}} \pm 0.24$ & $25.80^{\mathrm{a}} \pm 0.37$ \\
\hline PN 128 & $26.65^{\mathrm{a}} \pm 0.18$ & $18.50^{\mathrm{b}} \pm 0.26$ & $0.88^{\mathrm{a}} \pm 0.01$ & $218.20^{\mathrm{b}} \pm 1.53$ & $16.40^{\mathrm{b}} \pm 0.24$ & $11.60^{\mathrm{b}} \pm 0.24$ & $23.80^{\mathrm{b} \pm 0.24}$ \\
\hline TL3 & $26.72^{\mathrm{a}} \pm 0.15$ & $20.75^{\mathrm{a}} \pm 0.42$ & $0.84^{\mathrm{a}} \pm 0.01$ & $228.80^{\mathrm{a}} \pm 2.24$ & $16.80^{\mathrm{b}} \pm 0.20$ & $12.00^{\mathrm{b}} \pm 0.32$ & $24.20^{\mathrm{b}} \pm 0.24$ \\
\hline
\end{tabular}

Leaf length, leaf width, stem diameter, stem height, number of vegetative shoots, female flowers, and male flower of three muskmelon cultivars including RZ F1, PN 128, and TL3 growing on the spent mushroom substrate. Values are mean \pm SEM, $n=30$. Means labelled with the same letter were not significantly different at the $\mathrm{P}<0.05$ level (Tukey's HSD), see Table 2 for details of ANOVA results. + Measured until the plants had 23-24 true leaves, and the top of plants were pruned. 
Table 4 Effect of spent mushroom substrate on the fruit morphology of three muskmelon seedling cultivars

\begin{tabular}{|c|c|c|c|c|c|}
\hline $\begin{array}{l}\text { Muskmelon } \\
\text { cultivars }\end{array}$ & $\begin{array}{l}\text { Fruit } \\
\text { shape }\end{array}$ & $\begin{array}{l}\text { Fruit peel } \\
\text { colour }\end{array}$ & Fruit flesh colour & Skin phenotype & Skin image \\
\hline RZ F1 & Circle & Yellow & White and slightly blue & Thick, clear, and white reticular & \\
\hline PN 128 & Oval & $\begin{array}{c}\text { Blue with } \\
\text { slightly yellow }\end{array}$ & Orange & Thick, clear, and white reticular & \\
\hline TL3 & Circle & Dark blue & Orange & Thick, clear, and white reticular & \\
\hline
\end{tabular}

Fruit shape, fruit peel colour, fruit colour, skin phenotype of three muskmelon cultivars including RZ F1, PN 128, and TL3 growing on spent mushroom substrate measured at the harvest day.

a)

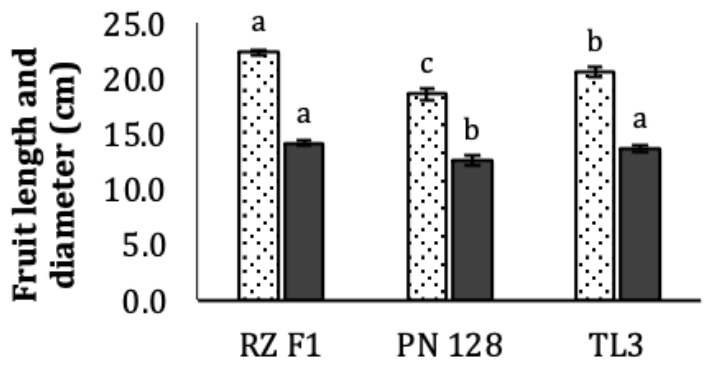

口Fruitlength $\square$ Fruit diameter

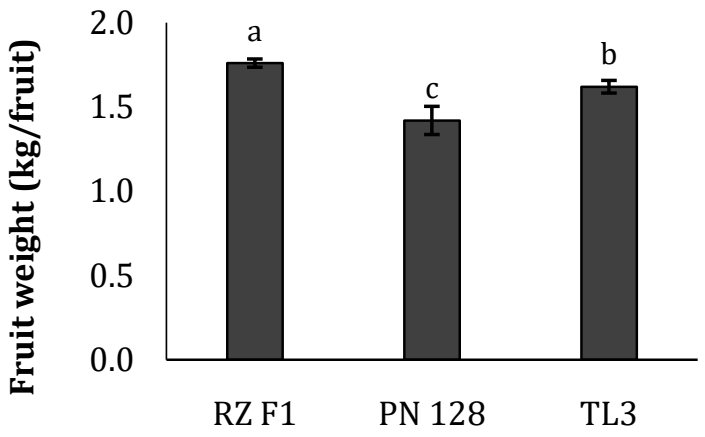

d)

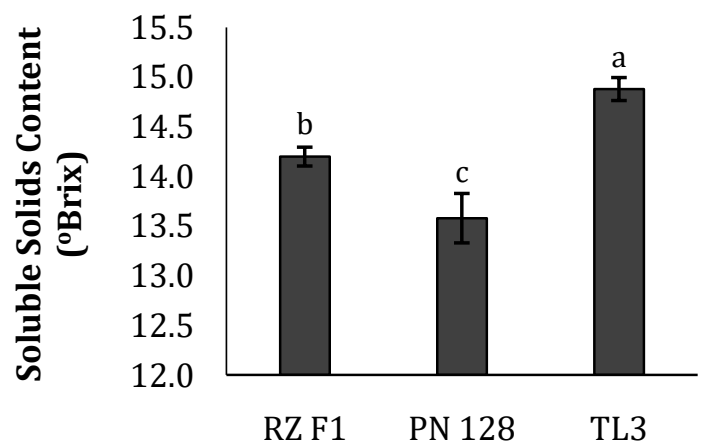

Figure 2 Fruit length and diameter (a), fruit weight (b), the thickness of pericarp (c), and soluble solids content (d) of three muskmelon cultivars including RZ F1, PN 128, and TL3 fruits growing on the spent mushroom substrate. Values are mean \pm SEM, $n=30$. Means labelled with the same letter were not significantly different at the $\mathrm{P}<0.05$ level (Tukey's HSD), see Table 2 for details of ANOVA results. 


\section{Discussion}

The current study first time reported that spent mushroom substrate can be used to grow different varieties of muskmelons. Mixing the substrate with manure and Trichoderma preparation, reducing the $\mathrm{pH}$ of the spent mushroom substrate to a neutral $\mathrm{pH}$ (6.54), which is the optimal $\mathrm{pH}$ condition for plant and microorganism growth. Wancke suggested that cucurbit species, especially muskmelons require a $\mathrm{pH}$ between 6.0 and 6.8 for optimal growth (Wancke, 2007). During incubation, microorganisms in the preparation degrade the organic matter in the substrate, releasing $\mathrm{H}+$ and the substrate becomes more acidic, altering the $\mathrm{pH}$ of the soil or substrate (Sylvia et al., 2005; Tripathi et al., 2013).

Incubation also increased the nutrient content including $\mathrm{N}, \mathrm{P}_{2} \mathrm{O}_{5}$, and $\mathrm{K}_{2} \mathrm{O}$ in the substrate. Microorganisms secrete enzymes that help in converting the organic matter in the substrate to easy-todigest nutrients that are beneficial to plants (Jacoby et al., 2017). The OM\% in the spent mushroom substrate was $37.47 \%$ which greatly exceeds Vietnam standards (TT41/2014-BNNPTNT) of $20 \%$ for organic fertilizers, mineral organic fertilizers, and bioorganic fertilizers. In addition, the phosphorus and potassium digestible contents in the substrate were substantially higher than those in the organic substrate which was studied by Nguyen (2016) to grow vegetables. Therefore, this spent mushroom substrate meets the standard to grow muskmelon plants.

The three muskmelon cultivars in this experiment were short-term commercial muskmelon varieties, which required about 70 to 75 days to completing their life cycle according to producers. However, under the same condition, TL3 and RZ F1 muskmelon plants' growth took around 75 days which was better than PN 128 muskmelon plants. This difference might be due to the effect of spent mushroom substrate on PN 128 plants. In addition, Beattie \& Doolittle (1951) pointed out that commercial muskmelon plants will take longer to complete their life cycle in undesirable conditions (Beattie \& Doolittle, 1951). The RZ F1 life cycle on the spent mushroom substrate was 6 days longer than that of RZ F1 plants grown on fluvisols without annual accretion (Truong et al., 2019). This could be because this cultivar was grown during a different season (spring in our study rather than summer-autumn in Truong's study) and fruit ripening depends on temperature (Kyriacou et al., 2018). The higher temperature leads to an increase in fruit respiration and the fruit produces ethylene gas which stimulates chlorophyll degradation and ripening.

Leaf length and width are important growth indices of plant development (Shi et al., 2019). TL3 muskmelon plants exhibited the best leaf growth in the spent mushroom substrate. However, the RZ F1 plants showed the highest number of vegetative shoots, female and male flowers. This might be due to the characteristic of each cultivar so each of them had different morphology indicators.
Compared to other studies, the leaf lengths of the three cultivars in the current experiment were slightly lower than that of Cucumis melo cv. Earl's Tokai PF700 grown in hydroponic culture (Fukuda \& Anami, 2001). On the other hand, the plant height of these three cultivars grown on the spent mushroom substrate was dramatically higher than that of Cucumis melo cv. Earl's Tokai PF700 (Fukuda \& Anami, 2001), and Cantaloupe plants grown in soil, supplemented with organic manure and NPK fertilizers (Shafeek et al., 2015).

In previous studies, it was reported that measures of fruit quality include both external and internal properties (Dorais \& Ehret, 2008; Omar \& MatJafri, 2013). External quality is usually determined by appearance, colour, size, bruises, and skin phenotype. Internal quality mainly concerns taste, flavour, texture, aroma, flesh firmness, diseases, chemical residues, and nutritional quality (soluble solids content, organic acids, antioxidant activity, total flavonoids, and so on). Based on the criteria above, this study concentrated on the external quality including fruit shape, fruit peel, and flesh colour and skin phenotype, as well as on the soluble solids content (internal quality).

Muskmelon fruit length and diameter, when grown on the spent mushroom substrate, was higher for RZ F1 than the two other cultivars. These indicators correlated with fruit weight. It was surprising that the yield of RZ F1 muskmelons was higher than that of RZ F1 muskmelons grown on fluvisols without annual accretion (Truong et al., 2019). Although the fruit weight of TL3 was lower than that of RZ F1, it was still within acceptable producer standards $(1.3-1.7 \mathrm{~kg} /$ fruit), and this was higher than the fruit weight of rockmelon grown on coconut coir dust culture (around $1.4 \mathrm{~kg} /$ fruit) (Wira et al., 2011). The yield of PN 128 muskmelon fruit was relatively low on the spent mushroom substrate. Further study of the substrate, greenhouses, and weather conditions are required to maximize PN 128 muskmelon growth and yield.

Sweetness is a pivotal component in the appreciation of muskmelon flavor. Soluble solids content (SSC) is accepted as an important quality characteristic to assess fruit quality because the major soluble solids are sugars (Pessarakli, 2016). Several previous studies have been carried out to evaluate the main factors affecting the soluble solids concentration in melon fruits. It has been reported that the major factors that affect the SSC are soil moisture (Wang et al., 2017), mineral nutrition (Cabello et al., 2009), genetic factors (Argyris et al., 2017; Kyriacou et al., 2018), drought conditions (Hongtao et al., 2020) and growth regulators (Acharya et al., 2020; Su et al., 2018). In the current study, the spent mushroom substrate affected the SSC of three muskmelon cultivars, and it was shown that the SSC of RZ F1 and TL3 fruit (around $15^{\circ}$ Brix) was higher than that of PN 128 fruits. This figure was also higher than those obtained in previous muskmelon studies 
(Truong et al., 2019; Wira et al., 2011; Nguyen et al., 2020). Further, Pessarakli (2016) indicated that the soluble solids content of melon cultivars within the range of $12^{\circ}$ Brix to $16^{\circ}$ Brix is accepted for standard melon commercial products. In conclusion, spent mushroom substrate could be utilized as an organic substrate for the economic cultivation of high-quality Inthanon RZ F1 and TL3 muskmelon fruit in Vietnam.

\section{Conclusions}

This study presents, to the best of our knowledge, the first evidence that spent mushroom ( $P$. ostreatus, and $V$. volvacea) substrate can be used as an organic substrate for Inthanon RZ F1 and TL3 muskmelon plant growth. The morphological growth, fruit quantity, and quality indicators of RZ F1 and TL3 muskmelon plants were within the parameters of the producers. The spent mushroom substrate containing $45 \% P$. ostreatus and $V$. volvacea by-product, $30 \%$ manure fertilizer, $7.7 \%$ rice husks, $1.5 \%$ phosphorus, $0.2 \%$ commercial Trichoderma (Tribac), $0.1 \%$ rice bran, $15 \%$ sand, and $0.5 \%$ micronutrients is recommended for use. This study reports for the first time that spent mushroom substrate can be used to grow different varieties of muskmelons. This would not only contribute to reducing the huge waste of mushroom industry by-products but would also help in a sustainable agricultural solution for both the mushroom and melon production industries, providing high-quality healthy melon products to consumers. Further studies are necessary to assess plant growth and fruit quality of other kinds of muskmelons in this substrate.

\section{Acknowledgement}

The authors thank Dr. Derek Wilkinson for proofreading the manuscript. This work was supported by Hue University under the Core Research Program, Grant No. NCM.DHH2020.13

\section{Authors' contribution}

T.O.N. and T.K.C.N. designed the experiment. T.D.N. and T.O.N. carried out the sample. H.T.H.T. and T.T.H.L evaluated data analyses. T.D.N. and T.O.N. prepared all of the figures, and all authors contributed to data interpretation. T.O.N and T.D.N. wrote the first draft of the manuscript and T.K.C.N edited the draft. All authors reviewed the manuscript.

\section{Conflicts of interest and financial disclosures}

The authors declare no competing interests.

\section{References}

Acharya SK, Thakar C, Brahmbhatt JH, Joshi N (2020) Effect of plant growth regulators on cucurbits: A. Journal of Pharmacognosy and Phytochemistry 9(4): 540-544.
Antunes F, Marçal S, Taofiq O, Morais AMMB, Freitas AC, Ferreira ICFR, Pintado M (2020) Valorization of mushroom byproducts as a source of value-added compounds and potential applications. Molecules 1-40. DOI: https://doi.org/10.3390/ molecules25112672.

Argyris JM, Díaz A, Ruggieri V, Fernández M, Jahrmann T, Gibon Y, Garcia-Mas J (2017) QTL analyses in multiple populations employed for the fine mapping and identification of candidate genes at a locus affecting sugar accumulation in melon (Cucumis melo L.). Frontiers in Plant Science 8: 1679. DOI: https://doi.org/10.3389/fpls.2017.01679.

Asaduzzaman M, Talukder M, Tanaka H, Ueno M, Kawaguchi M, Yano S, Asao T (2018) Production of low-potassium content melon through hydroponic nutrient management using perlite substrate. Frontiers in Plant Science 9: 1382. DOI: https://doi.org/10.3389/fpls.2018.01382.

Basham CW, Ells JE (1988) Cucumbers, pumpkins, squash, muskmelons, and watermelons for the home garden. Colorado State University. Libraries.

Beattie JH, Doolittle SP (1951) Muskmelons. US Department of agriculture. United State.

Bradstreet RB (1954) Kjeldahl method for organic nitrogen. Analytical Chemistry 26(1): 185-187.

Cabello MJ, Castellanos MT, Romojaro F, Martinez-Madrid C, Ribas F (2009) Yield and quality of melon grown under different irrigation and nitrogen rates. Agricultural Water Management 96(5): 866-874. DOI: https://doi.org/10.1016/j.agwat.2008.11.006.

Dorais M, Ehret DL (2008) Agronomy and the nutritional quality of fruit. CRC Press, Woodhead Publishing: Cambridge, UK.

Dube J, Ddamulira G, Maphosa M (2020) Watermelon production in Africa: challenges and opportunities. International Journal of Vegetable Science 1-9. DOI: https://doi.org/10.1080/ 19315260.2020 .1716128$.

Eshed Y, Zamir D (1994) Introgressions from Lycopersicon pennellii can improve the soluble-solids yield of tomato hybrids. Theoretical and Applied Genetics 88(6-7): 891-897.

FAO (2020) Melons and others. Retrieved 25 October 2020, from http://www.fao.org/faostat/en/\#data/QC.

Fatahian V, Halim RA, Ahmad I, Chua K, Teh CBS, Awang Y (2012) Melon production using four hydroponic systems. Acta Horticulturae 1004: 85-92. DOI: 10.17660/ActaHortic.2013.1004.8. 
Fiske CH, Subbarow Y (1925) The colorimetric determination of phosphorus. Journal of Biological Chemistry 66(2), 375-400.

Fu X, Li J, Zhou Y, Ying Y, Xie L, Niu X, Yu H (2009) Determination of soluble solids content and acidity of loquats based on FT-NIR spectroscopy. Journal of Zhejiang University Science B 10(2): 120. DOI: https://doi.org/10.1631/jzus.B0820097.

Fukuda N, Anami Y (2001) Substrate and nutrient level: Effects on the growth and yield of melon 'Cucumis melo' in soilless culture. Acta Horticulturae 588: 111-117. DOI: 10.17660/ActaHortic.2002.588.16.

Hanafi FHM, Rezania S, Taib SM, Din MFM, Yamauchi M, Sakamoto M, Ebrahimi SS (2018) Environmentally sustainable applications of agro-based spent mushroom substrate (SMS): an overview. Journal of Material Cycles and Waste Management 20(3): 1383-1396. DOI: https://doi.org/10.1007/s10163-018-0739-0.

Hongtao DO, Yunxia WU, Yurong LU, Tao ZH, Minqiang LI, Ling ZH (2020) A New Netted Muskmelon Cultivar 'Ximi 6' Tolerant to Low Temperature and Poor Light. Acta Horticulturae Sinica 47(S2): 3013-3014. DOI: 10.16420/j.issn.0513-353x.2020-0126.

Ikeda H, Tagami K, Fukuda N (1996) A study on a simple passive hydroponic system for melon production. Journal of the Japanese Society for Horticultural Science 64(4): 839-844.

Ito H, Morimoto S, Yamauchi R, Ippoushi K, Azuma K, Higashio $\mathrm{H}$ (2001) Potential of near infrared-spectroscopy for nondestructive estimation of soluble solids in watermelons. Acta Horticulturae 588: 353-356. 10.17660/ActaHortic.2002.588.57.

Jacoby R, Peukert M, Succurro A, Koprivova A, Kopriva S (2017) The role of soil microorganisms in plant mineral nutrition-current knowledge and future directions. Frontiers in Plant Science 8: 1617. DOI: https://doi.org/10.3389/fpls.2017.01617.

Kyriacou MC, Leskovar DI, Colla G, Rouphael Y (2018) Watermelon and melon fruit quality: The genotypic and agroenvironmental factors implicated. Scientia Horticulturae 234: 393 408. DOI: https://doi.org/10.1016/j.scienta.2018.01.032.

Lester GE (1997) Melon (Cucumis melo L.) Fruit nutritional quality and health functionality. HortTechnology 7(3): 222-227. DOI: https://doi.org/https://doi.org/10.21273/HORTTECH.7.3.222.

Lester GE (2008) Antioxidant, sugar, mineral, and phytonutrient concentrations across edible fruit tissues of orange-fleshed honeydew melon (Cucumis melo L.). Journal of Agricultural and Food Chemistry 56(10): 3694-3698. DOI: https://doi.org/10.1021/jf8001735.
Lester GE, Hodges DM (2008). Antioxidants associated with fruit senescence and human health: Novel orange-fleshed non-netted honeydew melon genotype comparisons following different seasonal productions and cold storage durations. Postharvest Biology and Technology 48(3): 347-354. DOI: https://doi.org/10.1016/j.postharvbio.2007.11.008.

Mrema E, Maerere AP (2018) Growth and yield performance of watermelon during dry and wet seasons under tropical conditions. International Journal of Vegetable Science 24(5): 483-489. DOI: https://doi.org/10.1080/19315260.2018.1439554.

Nguyen TM (2016) The process of treating mushroom residues as microbiological organic fertilizer. Vietnam Journal of Agriculture Science, 14(11): 1781-1788.

Nguyen TD, Nguyen TO, Truong THH, La TTH, Nguyen TKC (2020) Study on the growth and development of Inthanon RZ F1 (Cucumis melon L.) on different mushroom by-product substrates. In Processing of 2020 Vietnam National Conference of Biotechnology (544-549). Thua Thien Hue: Vietnam. 27 October 2020. Retrieved from http://huib.hueuni.edu.vn/hoi-nghi/nam2020/bao-cao-khoa-hoc/.

Nguyen TD (2019) Review of postharvest rice straw use: change in use and the need for sustainable management policies in Vietnam. Journal of Vietnamese Environment 11(2): 95-103.

Nguyen VT, Wang, CH (2017) Use of organic materials as growing media for honeydew melon seedlings in organic agriculture. Communications in Soil Science and Plant Analysis 48(18): 21372147. DOI: https://doi.org/10.1080/00103624.2017.1407431.

Omar AF, MatJafri MZ (2013) Principles, methodologies and technologies of fresh fruit quality assurance. Quality Assurance and Safety of Crops \& Foods 5(3): 257-271. DOI: https://doi.org/10.3920/QAS2012.0175.

Othman NZ, Sarjuni MNH, Rosli MA, Nadri MH, Yeng LH, Ying OP, Sarmidi MR (2020) Spent Mushroom Substrate as Biofertilizer for Agriculture Application. In Valorisation of Agro-industrial Residues-Volume I: Biological Approaches (pp. 37-57). Springer. Cham. DOI: https://doi.org/10.1007/978-3-030-39137-9_2.

Othman Y, Bataineh K, Al-Ajlouni M, Alsmairat N, Ayad J, Shiyab S, St Hilaire R (2019) Soilless culture: Management of growing substrate, water, nutrient, salinity, microorganism and product quality. Fresenius Environmental Bulletin 28: 3249-3260.

Pessarakli M (2016) Handbook of Cucurbits: growth, cultural practices, and physiology. CRC Press. 
Rinker DL (2002) Handling and using "spent" mushroom substrate around the world. Mushroom Biology and Mushroom Products, UAEM, Cuernavaca.

Rinker DL (2017) Spent mushroom substrate uses. Edible and Medicinal Mushrooms: Technology and Applications. Wiley, Hoboken, 427-454.

Rodriguez JC, Shaw NL, Cantliffe DJ, Karchi Z (2005) Nitrogen fertilization scheduling of hydroponically grown 'Galia'muskmelon. Proceedings of the Florida State Horticultural Society 118: 106-112.

Schiavi M, Venezia A, Casarotti D, Martignon G (1994) Muskmelon cultivation on substrates. Acta Horticulturae 401: 265272. DOI: 10.17660/ActaHortic.1995.401.32.

Shafeek MR, Shaheen AM, Abd El-Samad EH, Rizk, FA, Abd ElAl FS (2015) Response of growth, yield and fruit quality of cantaloupe plants (Cucumis melo L.) to organic and mineral fertilization. Middle East Journal of Applied Sciences 5(1): 76-82.

Shi P, Liu M, Yu X, Gielis J, Ratkowsky DA (2019) Proportional relationship between leaf area and the product of leaf length and width of four types of special leaf shapes. Forests 10(2): 178. DOI: https://doi.org/10.3390/f10020178.

Su H, Wang Q, Li C, Shao H, Jin M, Wang S, Wang H (2018) Effects of plant growth regulators thidiazuron on melon quality. Scientia Agricultura Sinica 51(16): 3095-3105.

Sylvia DM, Fuhrmann JJ, Hartel PG, Zuberer DA (2005) Principles and applications of soil microbiology. Pearson.

Thai News Service Group (2017) Vietnam: High-tech farming model helps farmers escape poverty. Asia News Monitor; Bangkok, Thailand. Retrieved from https://www.proquest.com/ newspapers/vietnam-high-tech-farming-model-helps-farmers/ docview/1977938609/se-2?accountid=135225.

Thakur H, Sharma S, Thakur M (2019) Recent trends in muskmelon (Cucumis melo L.) research: an overview. The Journal of Horticultural Science and Biotechnology 94(4): 533-547. DOI: https://doi.org/10.1080/14620316.2018.1561214.

Tripathi P, Singh PC, Mishra A, Chauhan PS, Dwivedi S, Bais RT, Tripathi RD (2013) Trichoderma: a potential bioremediator for environmental clean up. Clean Technologies and Environmental Policy 15(4): 541-550. DOI: https://doi.org/10.1007/s10098-0120553-7.

Truong THH (2018) Vegetable growing techniques. Hue University Press. Vietnam.

Truong THH, Chan NL, Nguyen TD (2019) Growth, yield and quality of melon (Cucumis melo L.) F1 hybrid varieties cultivated under plastic house conditions in spring-summer 2018 in Thua Thien Hue. Hue University Journal of Science: Agriculture and Rural Development 128(3A): 57-66. DOI: https://doi.org/10.26459/hueuni-jard.v128i3a.4965.

Walkley A, Black IA (1934) An examination of the Degtjareff method for determining soil organic matter, and a proposed modification of the chromic acid titration method. Soil Science 37: $29-38$.

Wancke DD (2007) Nutrient Management for Cucurbits: Melon, Pumpkin, Cucumber, and Squash. Indiana CCA Conference.

Wang J, Huang G, Li J, Zheng J, Huang Q, Liu H (2017) Effect of soil moisture-based furrow irrigation scheduling on melon (Cucumis melo L.) yield and quality in an arid region of Northwest China. Agricultural Water Management 179:167-76. DOI: https://doi.org/10.1016/j.agwat.2016.04.023.

Wira AB, Razi IM, Jamil, ZA (2011) Composts as additives in coconut coir dust culture for growing rockmelon (Cucumis melo L.). Journal of Tropical Agriculture and Food Science 39(2): 229237.

Yam RSW, Fan YT, Lin JT, Fan C, Lo HF (2020) Quality Improvement of Netted Melon (Cucumis melo L. var. reticulatus) through Precise Nitrogen and Potassium Management in a Hydroponic System. Agronomy 10(6): 816. DOI: https://doi.org/10.3390/agronomy10060816. 